\title{
SLEEP HABITS, SLEEPINESS AND ACCIDENTS AMONG TRUCK DRIVERS
}

\author{
José Carlos Souza', Teresa Paiva², Rubens Reimão³
}

\begin{abstract}
Objective: To evaluate the quality of sleep, shift work, alcohol and psychostimulant drug use, and the prevalence of accidents among truck drivers. Method: Data were collected using a demographic questionnaire, the Epworth Sleepiness Scale (ESS) and the Pittsburgh sleep quality index (PSQI). Statistical analysis was conducted using the Student $t$, chi-square, Pearson and Fisher tests. Results: $43.2 \%$ of the drivers drove over $16 \mathrm{~h}$ a day, and $2.9 \%$ worked shifts. Mean number of sleep hours/day was 5.97 \pm 1.47 ; $23.8 \%$ slept $<5$ hours; $50.9 \%$ made use of alcohol, $95.6 \%$ of caffeine, and $11.1 \%$ of amphetamines. Mean PSQI was 4.95 $\pm 2.56 ; 35.4 \%$ had a PSQI >5; 23 subjects snored more than three times a week (11.1\%). Mean ESS was $6.56 \pm 4.2 ; 21.7 \%$ had a score $>10$. In the preceding five years, 27 drivers $(13.1 \%)$ were involved in accidents, 5 of which resulted in injuries and 3 in deaths. Conclusion: Results showed a high prevalence of sleep disorders, use of alcohol and psychostimulant drugs, and accidents.
\end{abstract}

KEY WORDS: sleep, sleep habits, sleepiness, transit accidents, truck drivers.

\section{Hábitos de sono, sonolência e acidentes em caminhoneiros}

RESUMO - Objetivo: Avaliar a qualidade do sono, trabalho em turnos, consumo de álcool e psicoestimulantes, e a prevalência de acidentes, entre caminhoneiros. Método: Foram aplicados questionários demográficos, a Escala de Epworth e o Índice de Pittsburgh. A análise estatística foi feita com os testes t de Student, qui-quadrado, Pearson e Fisher. Resultados: 43,2\% dirigiam mais que $16 \mathrm{~h} / \mathrm{dia}$; 2,9\% faziam trabalho por t u rnos. A média de horas de sono foi 5,97 +/- 1,47. 23,8\% dormiam menos de 5 horas. 50,9\% faziam uso de bebida alcoólica; usavam cafeína $95,6 \%$ e anfetaminas $11,1 \%$. A média do PSQI foi 4,95 +/- 2,56; 35,4\% tinham o PSQI maior que 5; 23 sujeitos ressonavam mais que 3 vezes por semana (11,1\%). A ESE teve uma média de 6,56 +/- 4,2; $21.7 \%$ um escore superior a 10. Nos últimos cinco anos 27 motoristas (13,1\%) estiveram envolvidos em acidentes, 5 com feridos e 3 commort os. Conclusão: Foi alta a prevalência de distúrbios do sono, uso de álcool e estimulantes, e de acidentes.

PALAVRAS-CHAVE: sono, hábitos de sono, sonolência, acidentes de trânsito, caminhoneiros.

Sleep is an active, cyclic biological phenomenon necessaryfor survival ${ }^{1-3}$. One of the most frequent sleep disorders is excessive daytime sleepiness (EDS), which affects 4 to $12 \%$ of the general population. People with EDS may be affected by psychological stress, decreased productivity at work or school, and increased risk of accidents ${ }^{4,5}$. Excessive daytime sleepiness, reduced number of sleep hours, shift work, excessive driving time, use of alcohol and other drugs are predictive factors of automotive accidents ${ }^{6-15}$.

Stoohs et al. ${ }^{16}$ evaluated 90 commercial longhaul truck drivers 20 to 64 years of age, and found that EDS was one of the factors of greatest risk for road accidents. In the United States, McCartt et al. ${ }^{17}$ studied long-distance truck drivers and found that $47.1 \%$ had already fallen asleep at the wheel while driving. Multivariate logistic re g ression revealed that a reduced number of sleep hours was one of the 6 predictive factors of falling asleep at the wheel, together with EDS, arduous schedules with more hours of work and fewer hours off-duty, older age and more experience as a driver, and driving at night. In Finland, Häkkänen and Summala ${ }^{18}$ found that $21.0 \%$ of the 337 short-haul truck drivers in their study had problems staying alert in at least $20 \%$ of their drives; a reduced number of sleep hours was also a predictive factor. The comparison with accidents showed that $2.0 \%$ of the drivers reported sleepiness before the accident, $4.0 \%$, fatigue, and $13.0 \%$ had been driving for more than

Faculdade de Medicina de Lisboa, Lisbon, Portugal (FML); Universidade de São Paulo, São Paulo SP, Brazil (USP); Universidade Católica Dom Bosco, Campo Grande MS, Brazil (UCDB): 'Psychiatrist, Post-doctorate, Instituto de Medicina Molecular (IMM), FML, Professor, UCDB; ${ }^{2} \mathrm{Head}$ of the Neurology Service and of the EEG and Sleep Laboratory, Professor, FML, Head Researcher, Neurosciences and Pathophysiology Unit, IMM, FML; ${ }^{3}$ Neurologist, Professor, USP. This study presents partial results of post-doctorate thesis defended in the Molecular Medicine Institute, Faculdade de Medicina de Lisboa, Lisbon, Portugal.

Received 28 February 2005, received in final form 16 June 2005. Accepted 10 August 2005.

Dr. José Carlos Souza - Rua Theotônio Rosa Pires 88 - 79004-340 Campo Grande MS - Brasil. E-mail: josecarlossouza@uol.com.br 
10 hours. In New Zealand, Connor et al ${ }^{19}$. evaluated 588 car drivers traveling on roads using the Epworth Sleepiness Scale (ESS). They found that 3.1\% of the drivers had 5 or fewer hours of sleep in the p receding 24 hours, $7.9 \%$ had ESS scores between 10 and 15 , and $1.3 \%$ had high scores (16 to 24 ), a sign of severe EDS.

Sleep assessment can be conducted with the use of questionnaires, such as the Pittsburgh sleep quality index (PSQI), validated by Byusse et al. in 1989 and whose purpose is to assess the subjective quality of sleep and identify sleep disorders in the preceding 30 days. A PSQI total score greater than 5 is diagnostic of sleep disorders, and differentiates between people that have sleep of good quality from those with a poor quality sleep, with a sensitivity of $89.6 \%$ and specificity of $86.5 \%{ }^{20}$. Excessive daytime sleepiness can be measured with the ESS, a scale with a high degree of internal consistency (Cronbach $\alpha=0.88)^{21}$.

The statistics of the Brazilian Transportation Ministryshow that, of a total of 104862 accidents in 2003, the probable cause of 2372 fatal accidents with a total of 7100 deaths was "lack of attention", whereas the probable cause of other 80 fatal accidents was sleepiness. ${ }^{22}$

Therefore the purpose of this study was to evaluate the effect of EDS, reduced number of sleep hours, shift work, driving time, and use of alcohol and other drugs among truck drivers in Brazil, and to investigate their association with accidents involving professional and private drivers. This study is part of a larger epidemiological study comparing truck drivers in Brazil and Portugal.

\section{METHOD}

The data for this cross-sectional, comparative exploratory descriptive study were collected by means of a questionnaire about demographic data and habits, the ESS and the PSQI. A pilot study was conducted with 20 truck drivers. The sample was composed of 260 truck drivers working on federal roads in the State of Mato Grosso do Sul, Brazil, during 15 days. Each consecutive interview lasted 20 to 30 minutes; trained assistants individually interviewed the drivers at four gas stations, after informed consent.

The following factors were analyzed: subjective quality of sleep, sleep hours and sleep habits on working and off-duty days, shift work, sleep disorders, use of alcohol or psychostimulant drugs, prevalence of accidents in the last five years. Statistical analysis of data was conducted with the Student $t$ test, the chi-square test for contingency analysis, the Pearson correlation test, and the Fisher exact test. The level of significance was established at $5 \%$.

The study was approved by the Research Ethics Committee of Universidade Católica Dom Bosco, Campo Grande, Brazil. All subjects included in the study signed an informed consent form.

\section{RESULTS}

The drivers were all men, and their mean age was $38.2 \pm 10.6$ (21 to 79 years). Most drivers were married $(76.6 \%)$ and had a primary school education $(71.3 \%)$. Only $4.8 \%$ had another occupation, such as construction worker $(0.9 \%)$, and a few worked shifts $(2.9 \%)$ or had a fixed morning and afternoon schedule (2.4\%). Mean body mass index (BMl; weight/squareheight) was $27.64 \pm 4.34$ (19 to 43.9 $\left.\mathrm{kg} / \mathrm{m}^{2}\right) ; 14.6 \%$ had a BMl between 30 and $33 \mathrm{~kg} / \mathrm{m}^{2}$; $12.1 \%$ had a BMl equal to or greater than $33 \mathrm{~kg} / \mathrm{m}^{2}$.

The data on the number of driving hours revealed that $42.2 \%$ drove 11 to 15 hours a day, and $43.2 \%$ drove more than 16 hours a day (Fig 1). Considering these results for number of driving hours, only $2.9 \%$ worked shifts. Mean number of sleep hours on working days was $5.97 \pm 1.47$ ( 2 to

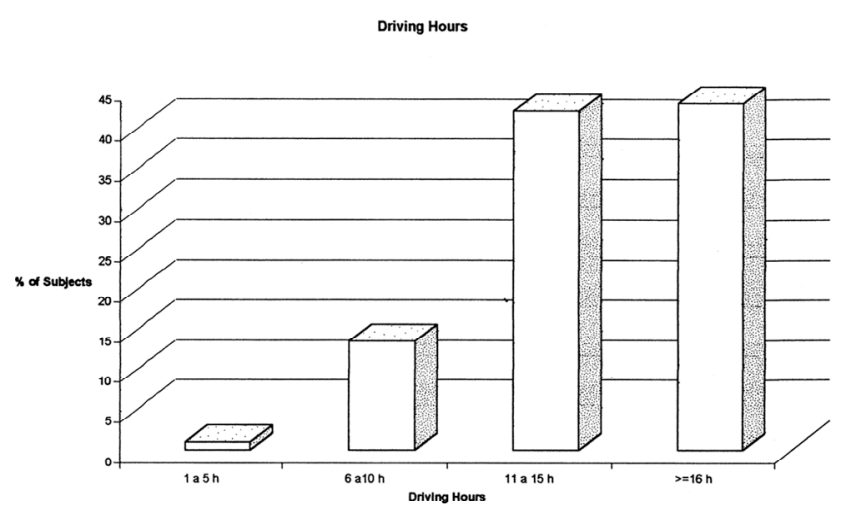


Table 1. Significant associations with the PSQI variable.

\begin{tabular}{lccccc}
\hline Categories & Brazil & Subcategory & $d f$ & $T$ & $P$ \\
\hline $\begin{array}{l}\text { Independent variable - PSQI } \\
\text { Sleep hours on working days }\end{array}$ & & & & & \\
$<5$ & $5.796+/-2.318$ & $<5 / 5-6$ & 151 & +1.738 & 0.0842 \\
$5-6$ & $4.981+/-2.869$ & $<5 / 7-8$ & 95 & +3.940 & 0.0002 \\
$7-8$ & $4.146+/-1.762$ & $5-6 / 7-8$ & 150 & +1.859 & 0.0650 \\
Wake-up time on working days & & & & & \\
$0-3$ & $6.000+/-2.582$ & $0-3 / 6-7$ & 70 & 2.39 & 0.0222 \\
$4-5$ & $5.567+/-2.626$ & $4-5 / 6-7$ & 200 & 5.278 & $<0.0001$ \\
$6-7$ & $3.676+/-1.896$ & & & & \\
\hline
\end{tabular}

Table 2. Significant associations with the ESS variable.

\begin{tabular}{lccccc}
\hline Categories & Brazil & Subcategory & df & T & P \\
\hline $\begin{array}{l}\text { Dependent variable - ESS } \\
\text { Education }\end{array}$ & & & & & \\
$\quad$ Primary & $6.99+/-4.33$ & Prim / Prof & 146 & - & - \\
Secondary & $5.345+/-3.507$ & Prim / Sec & 203 & 2.582 & 0.0105 \\
Sleep hours on working days & & & & & \\
$<5$ & $7.347+/-4.196$ & $<5 / 5-6$ & 151 & +1.341 & 0.1821 \\
5 to 6 & $6.423+/-3.781$ & $<5 / 7-8$ & 95 & +2.288 & 0.0244 \\
7 to 8 & $5.479+/-3.832$ & $5-6 / 7-8$ & 150 & +1.402 & 0.1630 \\
PSQI & & & & & \\
$<5$ & $6.068+/-3.928$ & & & & \\
$>5$ & $7.466+/-4.537$ & & & & \\
\hline
\end{tabular}

$10 \mathrm{~h}) ; 23.8 \%$ slept less than 5 hours, and about half $(50.4 \%)$ slept 5 to 6 hours. Only $23.3 \%$ slept 7 to 8 hours on working days, and only 5 drivers (2.4\%) slept more than 9 hours. On off-duty days, $47.5 \%$ slept 9 or more hours, $38.3 \%, 7$ to $8 \mathrm{~h}$, $11.6 \%, 5$ to $6 \mathrm{~h}$, and $2.4 \%$, less than $5 \mathrm{~h}$. On working days, $2.0 \%$ woke up between 0 and 3 a.m., $65 \%$ between 4 and 5 a.m., and $33 \%$ between 6 and 7 a.m. On off-duty days, $0.5 \%$ woke up between 0 and 3 a.m., $9.2 \%$ between 4 and 5 a.m., $39.3 \%$ between 6 and 7 a.m., $40.3 \%$ between 8 and 9 a.m., and $10.7 \%$ after 10 a.m.

Alcohol use was reported by $50.9 \%$ of the drivers; $8.7 \%$ drank more than six times a week, and $21.8 \%$, only once a week $(p<0.0001)$. The most common beverages were beer $(49.0 \%)$ and distilled liquor $(48.0 \%)(p<0.0001)$, Stimulant substances such as caffeine were used by $95.6 \%$ of the drivers, and cola drinks were the most frequent $(p<0$. 0001). Other stimulant substances, such as amphetamines (fenproporex and diethylpropion) were used by $11.1 \%(p<0.0001), 77.1 \%$ of which took it six or more times a week $(p<0.0001)$.

Mean PSQI was $4.95 \pm 2.56$ ( 0 to 16 ); $35.4 \%$ had a PSQI greater than 5. In addition, 23 subjects snored more than three times a week $(11.1 \%)$. The PSQI score was higher among those who slept fewer hours ( $<5 \mathrm{~h}$ or 5 to $6 h$ ) than in the group of drivers who slept 7 to 8 hours. It was also significantly higher in the group that woke up earlier, before 5 a.m. (Table 1).

Mean ESS was $6.56 \pm 4.2$ ( 0 to 24 ); $51.5 \%$ had scores below $6,16.5 \%$, between 7 and 8 , and $21.7 \%$, g reater than $10 ; 2.9 \%$ had scores greater than 16 (Fig 2). The ESS results were significantly different for drivers with a primary education and those with a secondary education, and were greater for those with less education. It was also greater for those who slept less than $5 \mathrm{~h}$ or between 5 to $6 \mathrm{~h}$ on working days than for those who slept 7 to $8 \mathrm{~h}$. Comparisons with drivers that slept more than 9 hours we re not possible because of the small number of 

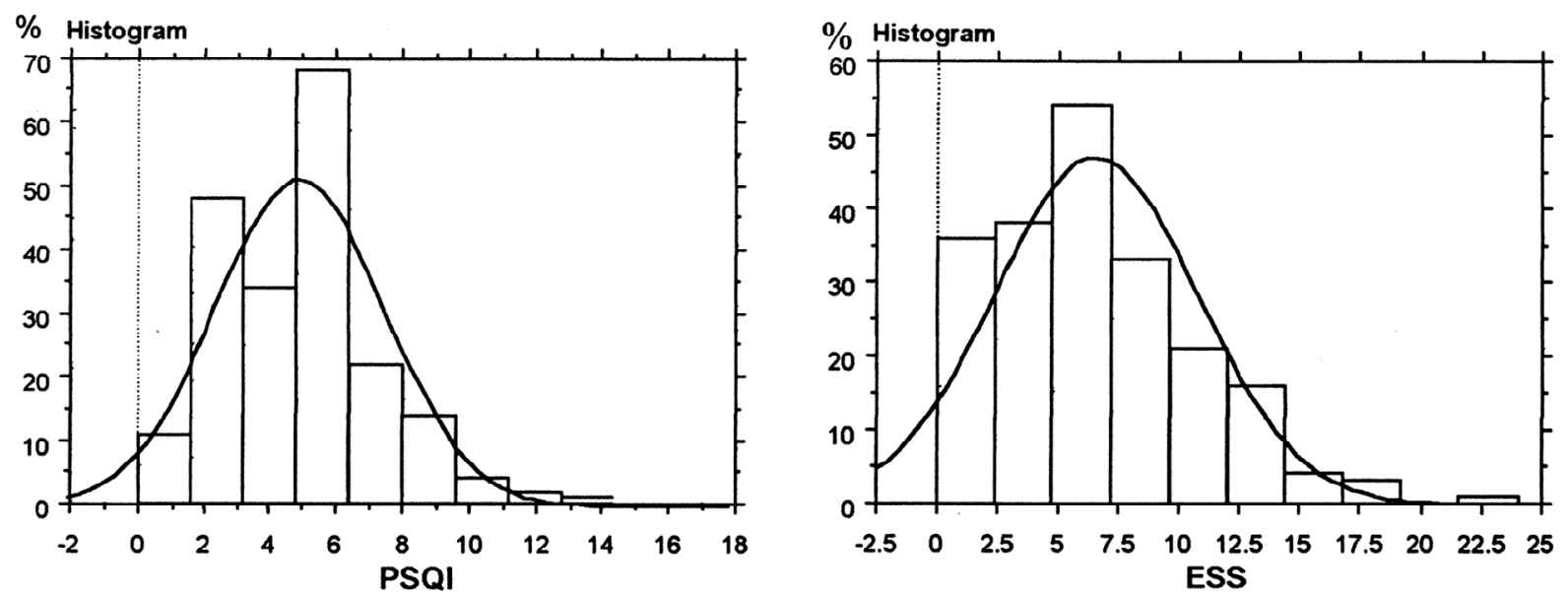

Fig 2. Distribution of mean PSQI and ESS scores.

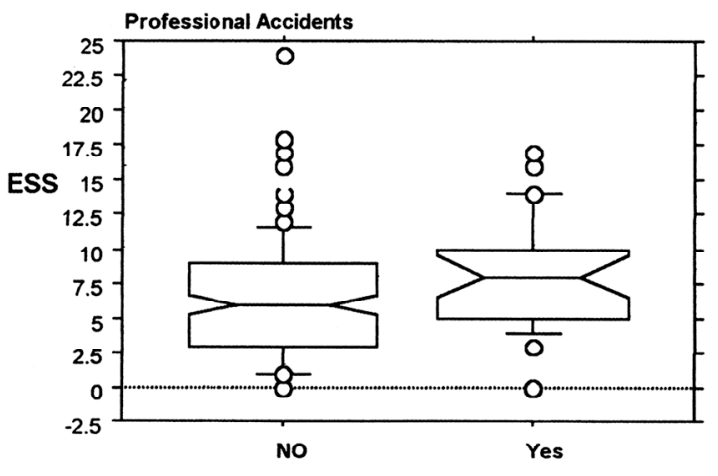

Fig 3. Box plot - distribution of number of professional acci dents and ESS.

drivers in this group. The ESE was also greater for drivers with a PSQI greater than 5. No significant diffe rence was found for number of driving hours per day (Table 2).

In the preceding five years 27 drivers (13.1\%) had been involved in accidents with their trucks, 5 of which resulted in injuries and 3 in deaths. Two drivers were involved in accidents with private cars; one resulted in injuries, and one in death.

The occurrence of accidents was significantly associated with age $(p=0.0311)$ : the group of drivers who had accidents had a lower mean age (34.1 \pm 8.98) than those who had not been involved in accidents (mean age $=38.8 \pm 10.7$ ). It was also significantly associated with EDS ( $p=0.0239)$ : mean EDS was $8.2 \pm 4.2$ in the group of drivers that had had accidents, and $6.3 \pm 4.1$ for those that had not (Fig 3). No significant differences in $\mathrm{BMI}$, driving hours, sleep hours, waking-up time, or use of alcohol and psy- chostimulant drugs were found between these 2 groups. No significant difference in PSQI was found between these groups, but all drivers that had been involved in accidents had a PSQI greater than 5 .

\section{DISCUSSION}

All drivers studied had life and work habits that negatively affected their daytime wakefulness, measured by the ESS, and the quality of their sleep, measured by the PSQI.

In our study, age and EDS were associated with accidents. Other studies have also shown that younger drivers (age below 25 years) are more frequently involved in accidents and have more fatal accidents ${ }^{23}$.

Benbadis ${ }^{24}$ points out that EDS is a symptom that leads to serious consequences, such as higher risks of automotive accidents. Therefore, it is important to initially diff e rentiate between a normal sensation of fatigue or sleepiness and actual EDS. Canani et al. ${ }^{13}$ found growing evidence that sleepiness might decisively contribute to the occurrence of accidents.

There are variations in the prevalence of EDS not only in the general population, but also among drivers, because of the diff e rent methodologies and evaluation instruments used in different studies ${ }^{19,25}$. Among drivers of urban buses, EDS prevalence ranges from $12.5 \%$ to $16.0 \%{ }^{26,27}$. Johns and Hocking ${ }^{28}$ conducted a study with 507 Australian workers using the ESS, and found an EDS prevalence of $10.9 \%$, which was not significantly associated with age (22 to 59 years), sex, obesity, or use of drugs, but was significantly associated with a reduced num- 
ber of sleep hours and insomnia. In Los Angeles, Bixler et al. ${ }^{29}$ found an EDS prevalence of $7.1 \%$. In Brazil, Souza et al. ${ }^{30}$ found a $14.0 \%$ prevalence in the general population of Campo Grande ${ }^{30}$. In New Zealand, Connor et al. ${ }^{19}$ evaluated 588 car drivers traveling on roads using the ESS, and found that $3.1 \%$ of them had had 5 or fewer hours of sleep in the preceding 24 hours; $7.9 \%$ had ESS scores between 10 and 15 , and $1.3 \%$ had high scores (16 to 24), which are knowingly associated with severe EDS. Häkkänen et al. ${ }^{26}$ and Souza et al..$^{27}$ found an EDS prevalence that ranged from 12.5 to $16.0 \%$ among urban bus drivers ${ }^{26,30}$. In this study, we found a prevalence of $21.7 \%$ for an ESS $>10$, and, as mentioned above, significantly greater values in the $g$ roup of drivers that had had accidents.

The statistics of the Brazilian Transportation Ministry suggest that the probable cause of 2372 accidents that resulted in 7100 deaths was lack of attention, and of 80 other accidents was sleepiness. However, in many of those cases there might have been a cause and effect relationship between the two probable causes. Stoohs et al. ${ }^{16}$ evaluated 90 commercial long-haul truck drivers 20 to 64 years of age, and found that EDS was one of the factors of greatest risk for road accidents. Their truck drivers reported 42 accidents. Their study used the same definition criteria adopted in our study - vehicle collided with any moving or static object, or ran off the road in the absence of any obstacles. Four drivers reported two accidents and two drivers reported 3 accidents in the preceding five years.

Another worrisome cause of accidents is the reduction in the number of sleep hours. In Australia, Arnold et al. ${ }^{9}$ found that about $38.0 \%$ of the truck drivers drove for more than 14 hours a day, and $51.0 \%$ also had another job; $12.0 \%$ of the truck drivers had slept fewer than 4 hours in one or more working days in the preceding week. In the United States, McCartt et al. ${ }^{17}$ studied long-distance truck drivers and found that a reduced number of sleep hours was a predictive factor of falling asleep at the wheel, together with EDS, arduous schedules with more hours of work and fewer hours off-duty, older age and more experience as driver, and driving at night. In their study, 47.1\% of the drivers reported having already fallen asleep at the wheel. In Finland, Häkkänen and Summala ${ }^{18}$ found that $21.0 \%$ of the short-haul truck drivers studied had problems staying alert in $20 \%$ of their drives; reduced number of sleep hours was also a p redictive factor. In our study, the reduction in sle- ep time was significantly associated with an increase in daytime sleepiness, but was not greater in the group of drivers that had had accidents. Moreover, $85.4 \%$ of the truck drivers drove more than 11 hours a day, which made it difficult to evaluate the association of this factor with accidents.

The work in shifts, associated with the reduction in sleep hours, is also a very frequent complicating factor among truck drivers. In Finland, Häkkänen and Summala ${ }^{18}$ found that $13.0 \%$ of the long-haul truck drivers were shift workers, and $40.0 \%$ of them had problems keeping alert. Truck drivers were responsible for $16.0 \%$ of all accidents. In our study with Brazilian truck drivers, only $2.9 \%$ were shift workers.

The use of alcohol and other drugs stands out in some studies as a predictive factor of EDS and road accidents. Crouch et al. ${ }^{8}$ evaluated 168 American truck drivers and found that $67 \%$ used one or more drugs. The most prevalent drugs in their study were cannabinoids and ethanol, each found in $13 \%$ of the drivers, followed by cocaine $(8.0 \%)$ and amphetamines (7.0\%). In Australia, Arnold et al. ${ }^{9}$ found that $8.6 \%$ of the truck drivers used alcohol, $25.7 \%$ used other drugs, and $23.5 \%$ used psychotropic drugs. The most frequently used drugs were cannabinoids (13.5\%), opioids, morphine, codeine and methadone (4.9\%), stimulant drugs (including caffeine) $(4.1 \%)$, benzodiazepine drugs $(4.1 \%)$, and other psychotropic drugs $(2.7 \%)$. In Brazil, Muller ${ }^{11}$ studied 48 professional drivers, and found that $27.0 \%$ of them, who were 40 to 44 years of age, made excessive use of alcohol, and $72.9 \%$ had a primary education. In our study, $50.9 \%$ of the truck drivers regularly used alcohol, but the use of cannabinoids, opioids and benzodiazepine drugs was not reported. The level of education of drivers in this study is similar to that described by other Brazilian authors. These results point to the u rgent need to develop primary prevention programs and campaigns and to improve control by authorities. Transportation companies and truck drivers should follow what the legislation determines about length of time driving, work schedules and shifts, because of the high number of truck drivers on long distance drives who do not get adequate rest. It is important to rethink life and working habits. In conclusion, brazilian truck drivers studied in the Mato Grosso do Sul region have inadequate work and sleep habits, characterized by a high number of work hours and a reduced number of sleep hours, usually of poor quality. 


\section{REFERENCES}

1. Kryger MH, Roth T, Dement WC. Principles and practice of sleep medicine, 2nd ed. Philadelphia: WB Saunders, 2000.

2. Chokroverty S. Sleep disorders medicine: basic science considerations and clinical aspects. Washington: Butterworth-Heinmann, 1999.

3. Culebras A. Clinical handbook of sleep disorders. Boston: ButterworthHeinemann, 1996.

4. Roth T, Roehrs TA. Etiologies and sequelae of excessive daytime sleepiness. Clin Ther 1996;18:562-576.

5. Weber SAT, Montovani JC. Doenças do sono associadas a acidentes com veículos automotores. Rev Bras Otorrinolaringol 2002;68:412-415.

6. Akerstedt T. Sleepiness as a consequence of shift work. Sleep 1988;11:17-34.

7. Aldrich MS. Automobile accidents in patients with sleep disorders. Sleep 1989;12:487-494.

8. C rouch DJ, Birky MM, Gust SW, et al. The prevalence of drugs and alcohol in fatally injured truck drivers. J Forensic Sci 1993;38:1342-1353.

9. Arnold PK, Hartley LR, Corry A, Hochstadt D, Penna F, Feyer AM. Hours of work and perceptions of fatigue among truck drivers. Accid Anal Prev 1997;29:471-477.

10. Maycock G. Sleepiness and driving: the experience of UK car drivers. Accid Anal Prev 1997;29:453-462.

11. Muller CN. The use of alcohol by professional drivers of motor vehicles. Tese Curitiba, 2000.

12. Akerstedt T, Fredlund P, Gillberg M, Jansson B. A prospective study of fatal occupational accidents - relationship to sleeping difficulties and occupational factors. J Sleep Res 2002;11:69-71.

13. Canani SF, Barreto SSM. Sonolência e acidentes automobilísticos. J Pneumol 2001;27:94-96.

14. Philip P, Vervialle F, Le Breton P, Taillard J, Horne JA. Fatigue, alcohol, and serious road crashes in France: factorial study of national data. $\mathrm{Br}$ Med J 2001;322:829-830.

15. D rummer $\mathrm{OH}$, Gerostamoulos J, Batziris $\mathrm{H}$, et al. The incidence of drugs in drivers killed in Australian road traffic crashes. Forensic Sci Int 2003; 134:154-162.

16. Stoohs RA, Itoi A, Guilleminault C, Dement WC. Tr a ffic accidents in commercial long-haul truck drivers: the influence of sleep-disordered breathing and obesity. Sleep 1994;17:619-623.
17. McCartt AT, Rohrbaugh JW, Hammer MC, Fuller SZ. Factors associated with falling asleep at the wheel among long-distance truck drivers. Accid Anal Prev 2000;32:493-504.

18. Häkkänen J, Summala H. Fatal traffic accidents among trailer truck drivers and accident causes as viewed by other truck drivers. Accid Anal Prev 2001;33:187-196.

19. Connor J, Norton R, Ameratunga S, Robinson E, Wigmore B, Jackson $R$. Prevalence of driver sleepiness in a random population-based sample of car driving. Sleep 2001;24:688-698.

20. Buysse DJ, Reynolds CF 3rd, Monk TH, Berman SR, Kupfer DJ. The Pittsburgh Sleep Quality Index: a new instrument for psychiatric practice and research. Psychiatry Res 1989;28:193-213.

21. Johns MW. A new method for measuring daytime sleepiness: the Epworth sleepiness scale. Sleep 1991;14:540-545.

22. Brasil, Ministério dos Transportes. Programa de Redução de Acidentes no Trânsito - PARE. Estatística de acidentes de trânsito nas rodovias federais do Brasil. Brasília: Ministério dos Transportes, 2003.

23. Souza JC. Sono, hábitos, qualidade de vida e acidentes em camionistas do Brasil e de Portugal. Tese. Lisboa: 2004.

24. Benbadis SR. Daytime sleepiness: when is it normal? When to refer? Cleve Clin J Med 1998;65:543-549.

25. Philip P, Taillard J, Guilleminault C, Quera-Salva MA, Bioulac B, Ohayon $\mathrm{M}$. Long distance driving and self-induced sleep deprivation among automobile drivers. Sleep 1999;22:475-480.

26. Häkkänen $H$, Summala $H$, Partinen $M$, Tiihonen $M$, Silvo J. Blink duration as an indicator of driver sleepiness in professional bus drivers. Sleep 1999;22:798-802.

27. Souza JC, Magna LA, Reimão R. Sonolência diurna excessiva em motoristas de ônibus urbanos de Campo Grande, MS. Rev Bras Neurol Psiq 2002;3:85-89.

28. Johns M, Hocking B. Excessive daytime sleepiness: daytime sleepiness and sleep habits of Australian workers. Sleep 1997;20:844-849.

29. Bixler EO, Kales A, Soldatos CR, Kales JD, Healey S. Prevalence of sleep disorders in the Los Angeles metropolitan area. Am J Psychiatry 1979;136:1257-1262.

30. Souza JC, Magna LA, Reimão R. Excessive daytime sleepiness in Campo Grande general population, Brazil. Arq Neuropsiquiatr 2002;60:558-562. 